\title{
Status Report on the MSRE TRANSFORM Model for Thermal- Hydraulic Benchmarking
}

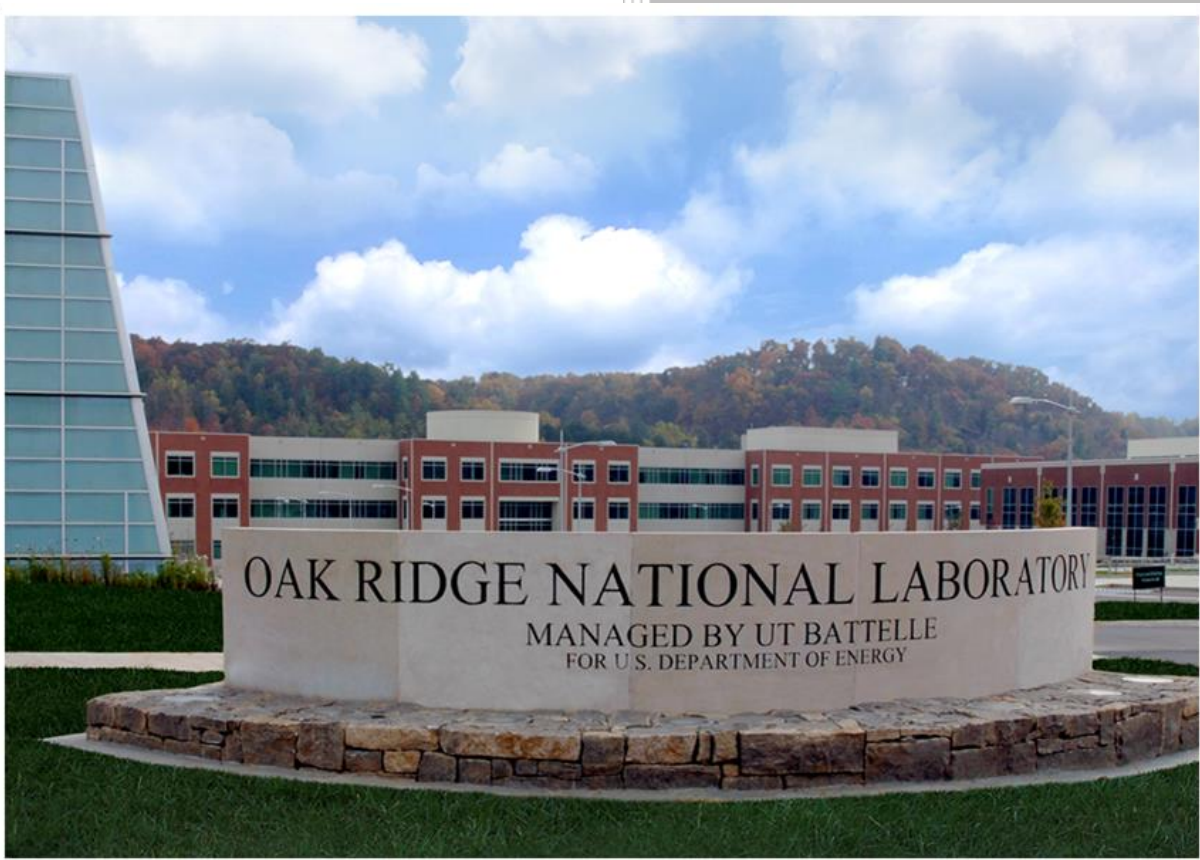

Dane de Wet M. Scott Greenwood

September 2019 


\title{
DOCUMENT AVAILABILITY
}

Reports produced after January 1, 1996, are generally available free via US Department of Energy (DOE) SciTech Connect.

Website www.osti.gov

Reports produced before January 1, 1996, may be purchased by members of the public from the following source:

\author{
National Technical Information Service \\ 5285 Port Royal Road \\ Springfield, VA 22161 \\ Telephone 703-605-6000 (1-800-553-6847) \\ TDD 703-487-4639 \\ Fax 703-605-6900 \\ E-mail info@ntis.gov \\ Website http://classic.ntis.gov/
}

Reports are available to DOE employees, DOE contractors, Energy Technology Data Exchange representatives, and International Nuclear Information System representatives from the following source:

Office of Scientific and Technical Information

PO Box 62

Oak Ridge, TN 37831

Telephone 865-576-8401

Fax 865-576-5728

E-mail reports@osti.gov

Website http://www.osti.gov/contact.html

This report was prepared as an account of work sponsored by an agency of the United States Government. Neither the United States Government nor any agency thereof, nor any of their employees, makes any warranty, express or implied, or assumes any legal liability or responsibility for the accuracy, completeness, or usefulness of any information, apparatus, product, or process disclosed, or represents that its use would not infringe privately owned rights. Reference herein to any specific commercial product, process, or service by trade name, trademark, manufacturer, or otherwise, does not necessarily constitute or imply its endorsement, recommendation, or favoring by the United States Government or any agency thereof. The views and opinions of authors expressed herein do not necessarily state or reflect those of the United States Government or any agency thereof. 
ORNL/TM-2019/1359

Reactor and Nuclear Systems Division

\title{
STATUS REPORT ON THE MSRE TRANSFORM MODEL FOR THERMAL-HYDRAULIC BENCHMARKING
}

\author{
Authors \\ Dane de Wet \\ M. Scott Greenwood
}

Date Published: September 2019

Prepared by OAK RIDGE NATIONAL LABORATORY

Oak Ridge, TN 37831-6283

managed by

UT-BATTELLE, LLC

for the

US DEPARTMENT OF ENERGY

under contract DE-AC05-00OR22725 



\section{CONTENTS}

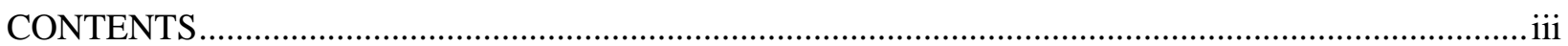

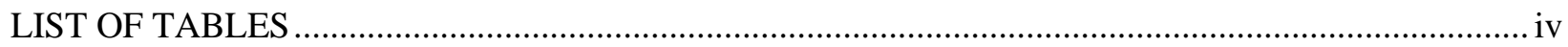

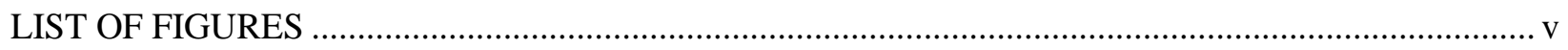

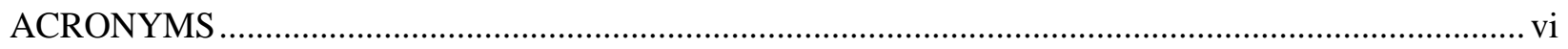

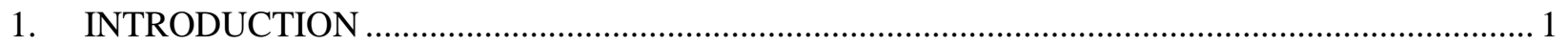

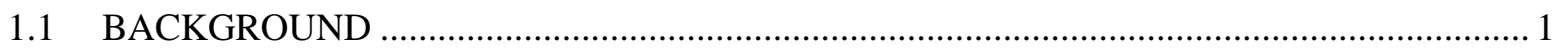

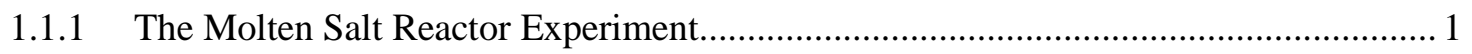

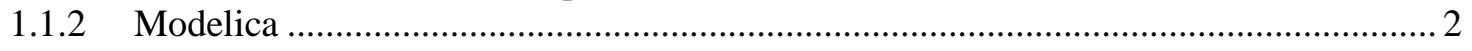

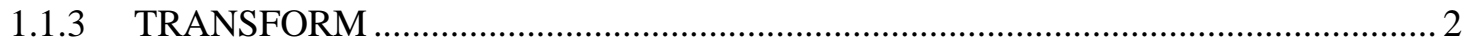

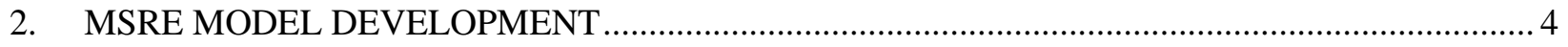

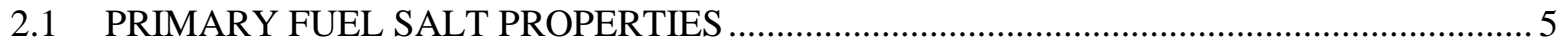

2.2 THERMAL-HYDRAULIC OVERVIEW OF THE MSRE CORE …................................. 6

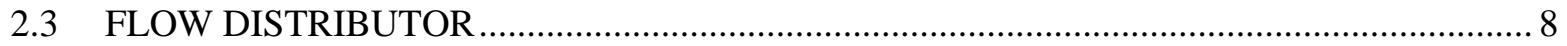

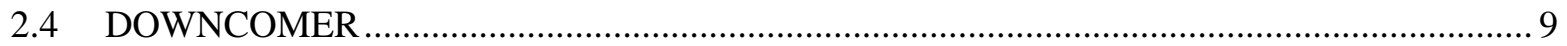

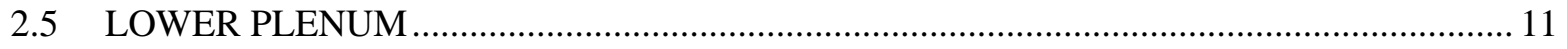

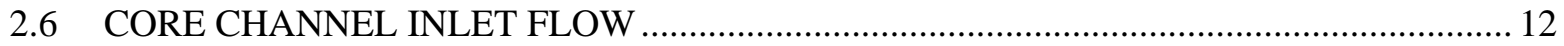

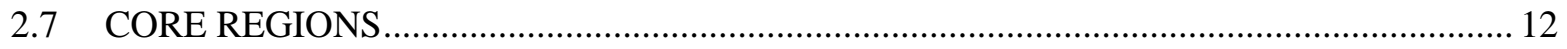

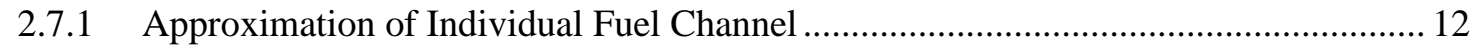

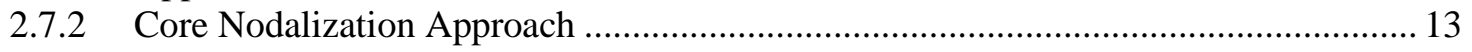

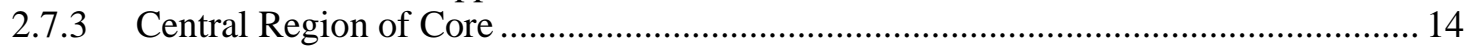

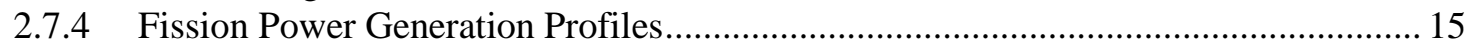

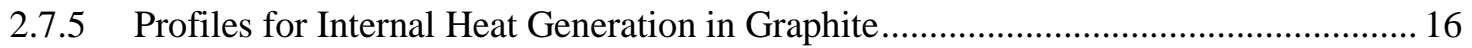

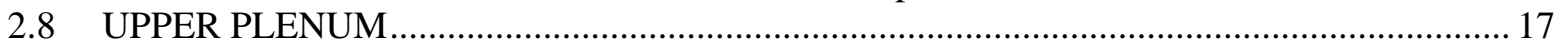

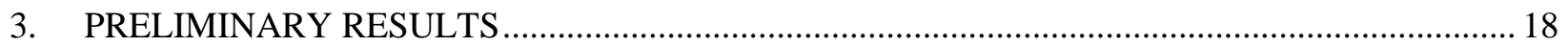

3.1 FREQUENCY DOMAIN COMPARISON OF CORE HEAT TRANSFER BEHAVIOR ...... 18

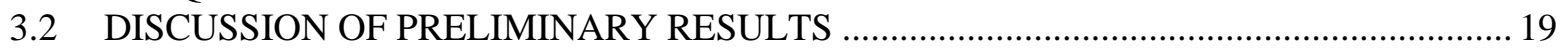

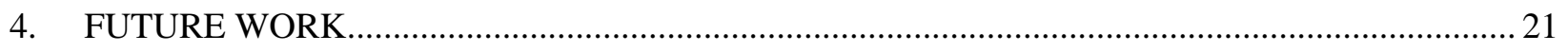

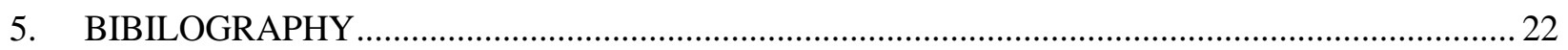




\section{LIST OF TABLES}

Table 1. MSRE Design and Operation Parameters.......................................................................... 3

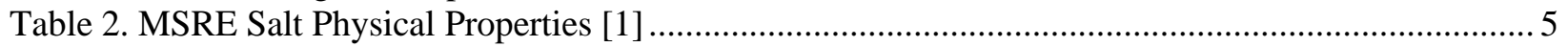

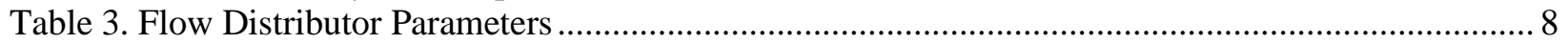

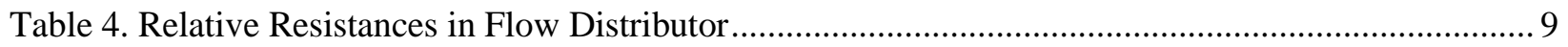

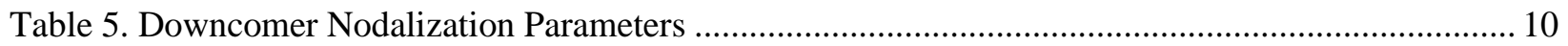

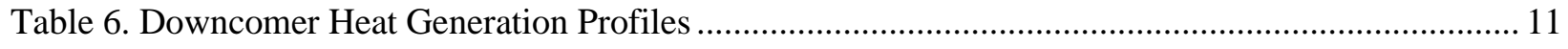

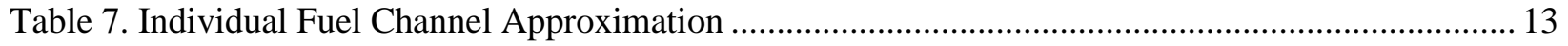

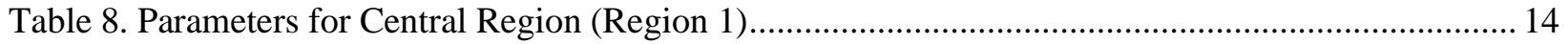

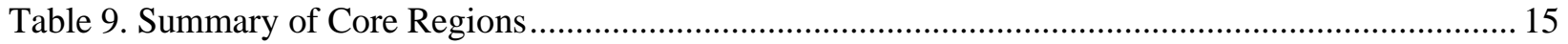




\section{LIST OF FIGURES}

Figure 1. Overview of the MSRE [3]

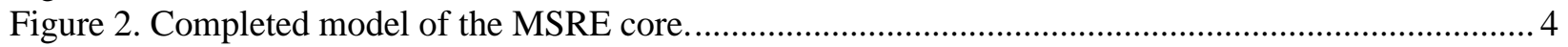

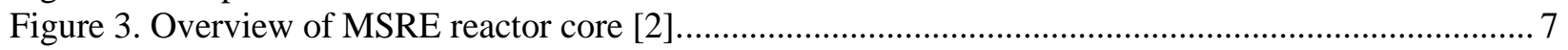

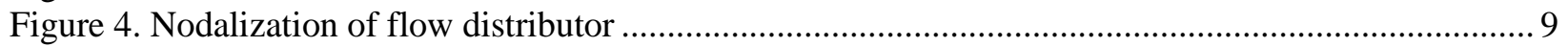

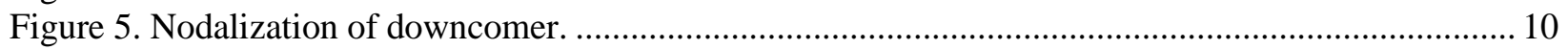

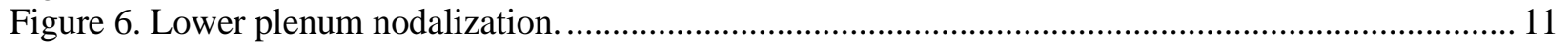

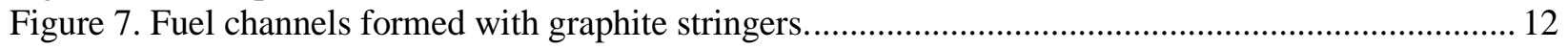

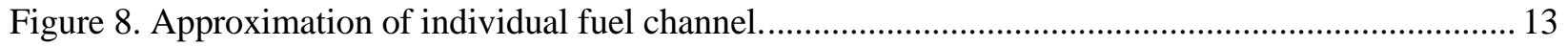

Figure 9. Horizontal cross-section of the MSRE core central region [3] .............................................. 14

Figure 10. Cross section of graphite core with regions 1-4 [18] .......................................................... 15

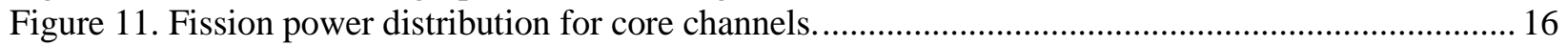

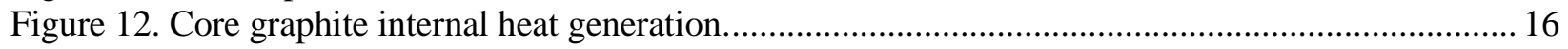

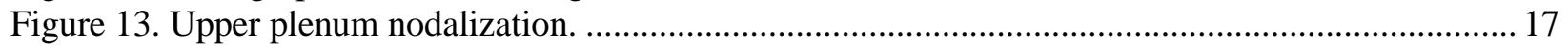

Figure 14. Comparison of frequency response for core outlet temperature to reactor power.................... 19

Figure 15. Preliminary nodalization for the full MSRE model............................................................. 21 


\section{ACRONYMS}

ORNL

TRANSFORM

MSRE

MWth

NHES
Oak Ridge National Laboratory

Transient Simulation Framework of Reconfigurable Models Molten Salt Reactor Experiment

megawatt thermal

nuclear hybrid energy system 


\section{INTRODUCTION}

Over the last several years, there has been renewed interest in the development of molten salt reactor concepts for the next generation of nuclear power plants. The modeling tools used to design these reactors must be validated in order to accurately predict the thermal hydraulic behavior expected during operation. The majority of the practical experience with molten salt reactors comes from the Molten Salt Reactor Experiment (MSRE) that operated at Oak Ridge National Laboratory (ORNL) from 1964 until 1969. The work discussed in this paper uses the design information and experimental data from that period to create and validate a detailed model of the MSRE. Once completed, this model's performance will be compared to other system analysis codes for thermal hydraulic benchmarking, and their ability to predict the thermal hydraulic performance of molten salt reactor systems will also be compared.

The model is being created with the Modelica-based modeling library TRANSFORM (Transient Simulation Framework of Reconfigurable Models), which was developed at ORNL for modeling complex thermal hydraulic energy systems. The initial efforts of this work focused on modeling the reactor core.

The performance of the reactor core model was then compared to the performance of previous models and available experimental data. Initial results show good agreement between the transient behavior of the model and results from experiments during operation.

Section 1 of this report covers the background on TRANSFORM and the MSRE. Section 2 addresses the creation of the model and the addition of the MSRE primary fuel salt properties to TRANSFORM.

Section 3 discusses the initial results from the model as they compare to the available experimental data. Finally, Section 4 provides information about future model development and the experimental data that will be used to validate the model's performance.

\subsection{BACKGROUND}

\subsubsection{The Molten Salt Reactor Experiment}

The MSRE was a graphite moderated, molten salt fueled nuclear reactor that was designed, built, and operated at ORNL in the 1960s [1]. The reactor was built as part of the Molten Salt Reactor Program for developing low-cost nuclear power plants for civilian power production. It used uranium tetrafluoride $\left(\mathrm{UF}_{4}\right)$ dissolved in a mixture of lithium, beryllium, and zirconium fluorides $\left(\mathrm{LiF}-\mathrm{BeF}_{2}-\mathrm{ZrF}_{4}\right)$ as the fuel and primary coolant [1]. It operated at a maximum full power of around 7.4 MWth [2].

The reactor reached its first criticality on June 1, 1965 and operated until December 12, 1969 [1]. During that time, it was critical for 17,655 hours, with 13,172 equivalent full-power hours [1]. The project was regarded as a success, as it accomplished the original objectives while providing considerable practical experience working with molten salts and developing components for molten salt reactors.

The reactor consisted of two main flow circuits: a primary loop, and a secondary loop. The primary loop consisted of the reactor core, the shell side of a shell-and-tube heat exchanger, piping, and a centrifugal pump for forced circulation [3]. The secondary loop consisted of the tube side of the shell-and-tube heat exchanger, the tube side of an air-cooled radiator, a centrifugal pump, and the associated piping [3]. Two blowers were used to force air over the radiator, which was then rejected to the atmosphere. The reactor also had a number of important auxiliary systems. These were mainly for heating, off-gas removal, salt processing, filling and draining, instrumentation, and component cooling. All metallic structures in contact with the salt were made from a high-nickel alloy called INOR-8, which was made commercially available as Hastelloy-N. Graphite was used as the moderator in the reactor core. 


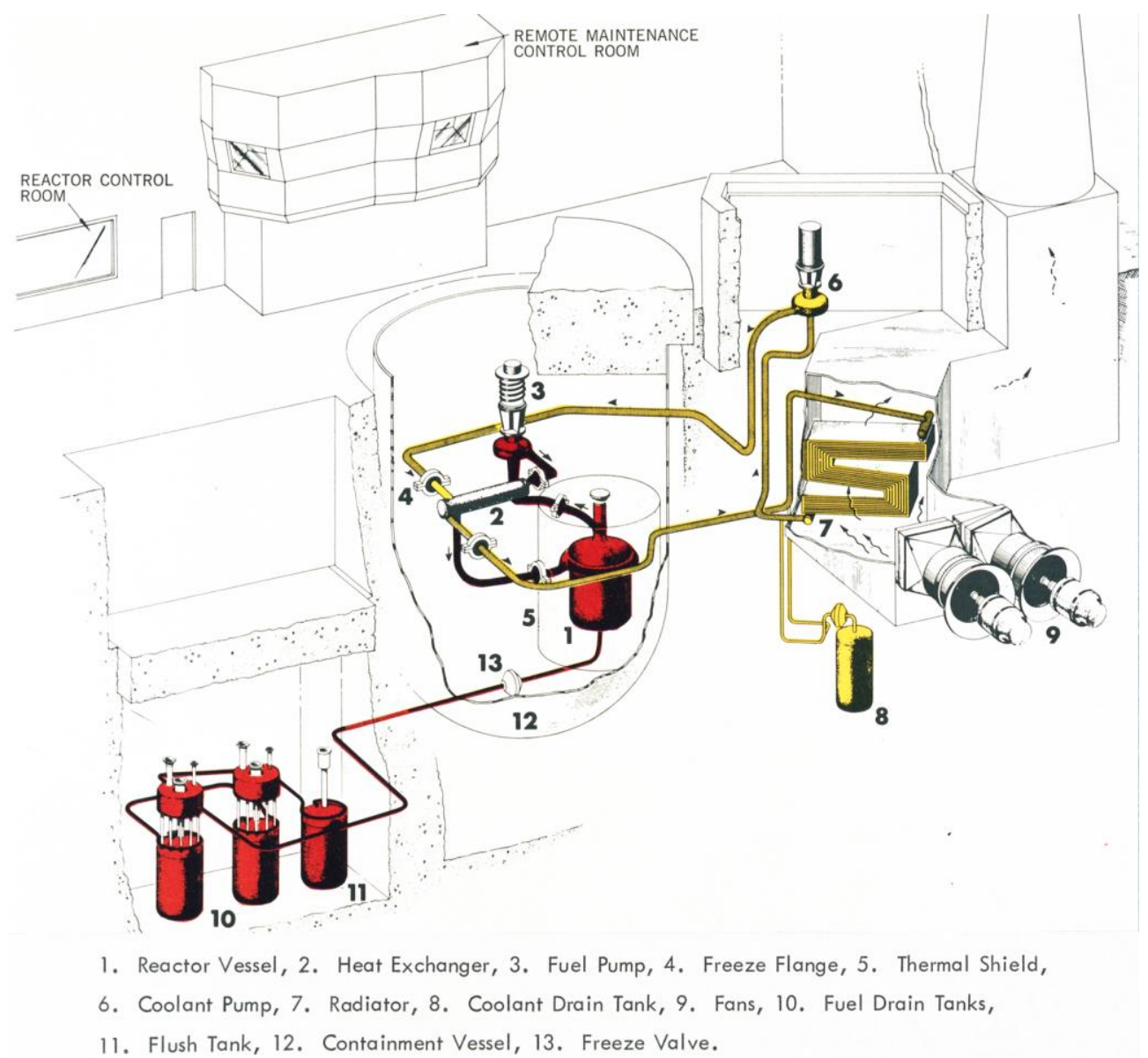

Figure 1. Overview of the MSRE [3]

\subsubsection{Modelica}

Modelica [4] [5] is a nonproprietary, object-oriented, equation-based programming language used to conveniently model complex physical and cyberphysical systems (e.g., systems containing components for mechanical, electrical, electronic, hydraulic, thermal, or control). A key advantage of Modelica is its separation of physical models and their solvers. This separation enables rapid generation of complex physical systems and control design in a single language without requiring knowledge of numeric solvers or code generation.

\subsubsection{TRANSFORM}

TRANSFORM [6] is a component library developed at ORNL using the Modelica programming language to investigate dynamic thermal hydraulic systems and other multiphysics systems. The TRANSFORM library has been successfully used for a variety of nuclear applications, including investigations into the performance of nuclear hybrid energy systems (NHESs) [7] [8]; liquid metal [9] and gas-cooled reactors [10]; and molten salt applications, including kinetic behavior and fission product transport [11] [12] [13]. 
Table 1. MSRE Design and Operation Parameters

\begin{tabular}{|c|c|}
\hline Parameter & Value \\
\hline Design full power & $10 \mathrm{MWth}$ \\
\hline Actual full power & 7.4 MWth \\
\hline Hot leg temperature & $654.4^{\circ} \mathrm{C}\left(1210^{\circ} \mathrm{F}\right)$ \\
\hline Cold leg temperature & $632.2^{\circ} \mathrm{C}\left(1170{ }^{\circ} \mathrm{F}\right)$ \\
\hline Core $\Delta T$ & $22.2^{\circ} \mathrm{C}\left(40^{\circ} \mathrm{F}\right)$ \\
\hline Primary flow rate & $\begin{array}{r}0.07571 \mathrm{~m}^{3} / \mathrm{s} \\
(1200 \mathrm{gpm})\end{array}$ \\
\hline Primary pressure & $0.03447 \mathrm{MPa}(5 \mathrm{psig})$ \\
\hline Primary fuel salt & $\mathrm{LiF}-\mathrm{BeF}_{2}-\mathrm{ZrF}_{4}-\mathrm{UF}_{4}$ \\
\hline Fuel melting point & $434{ }^{\circ} \mathrm{C}\left(813^{\circ} \mathrm{F}\right)$ \\
\hline Primary salt density & $\begin{array}{r}2241 \mathrm{~kg} / \mathrm{m}^{3} \\
\left(139.9 \mathrm{lb} / \mathrm{ft}^{3}\right) \\
\text { at } 650{ }^{\circ} \mathrm{C}\end{array}$ \\
\hline Moderator & Graphite \\
\hline Secondary salt & $\mathrm{LiF}_{-} \mathrm{BeF}_{2}$ \\
\hline Secondary loop hot leg temperature & $579^{\circ} \mathrm{C}\left(1075^{\circ} \mathrm{F}\right)$ \\
\hline Secondary loop cold leg temperature & $546^{\circ} \mathrm{C}\left(1015^{\circ} \mathrm{F}\right)$ \\
\hline Secondary loop mass flow rate & $\begin{array}{r}0.05363 \mathrm{~m}^{3} / \mathrm{s} \\
(850 \mathrm{gpm})\end{array}$ \\
\hline
\end{tabular}

From [1], [3], and [14] 


\section{MSRE MODEL DEVELOPMENT}

The initial modeling efforts of this project focused on accurately predicting the thermal hydraulic behavior of the reactor core. This was done to provide the required detail needed to produce an accurate representation of the complex heat generation and flow paths found in the core. The remainder of the MSRE consisted of piping, centrifugal pumps, a shell-and-tube heat exchanger, and an air-cooled radiator. These are more conventional components for thermal systems and do not require the same level of detail found in the reactor core. Additionally, previous modeling efforts have had difficulty with accurately predicting the transient heat transfer behavior of the reactor core, so those results have not compared well to the available experimental data [15]. Therefore, predicting the heat transfer in the core was considered a top priority and served as the focus of this work.

During the design of the MSRE, a full-scale mock-up of the reactor core was built and operated. It used water combined with a thickening agent as a simulant fluid for molten salts. This allowed designers to obtain accurate empirical measurements to aid in design verification [2]. These data from these efforts are important for understanding the thermal hydraulic behavior of the reactor core, as the instrumentation during operation was limited to thermocouples and neutron flux measurements. The core model for this project was created by combining this test loop data with predictions for the neutron flux profiles and internal heat generation in the structures. The completed model was then compared to transient data obtained from the reactor during operation, using measured operating temperatures and known flow rate as the inlet boundary conditions.

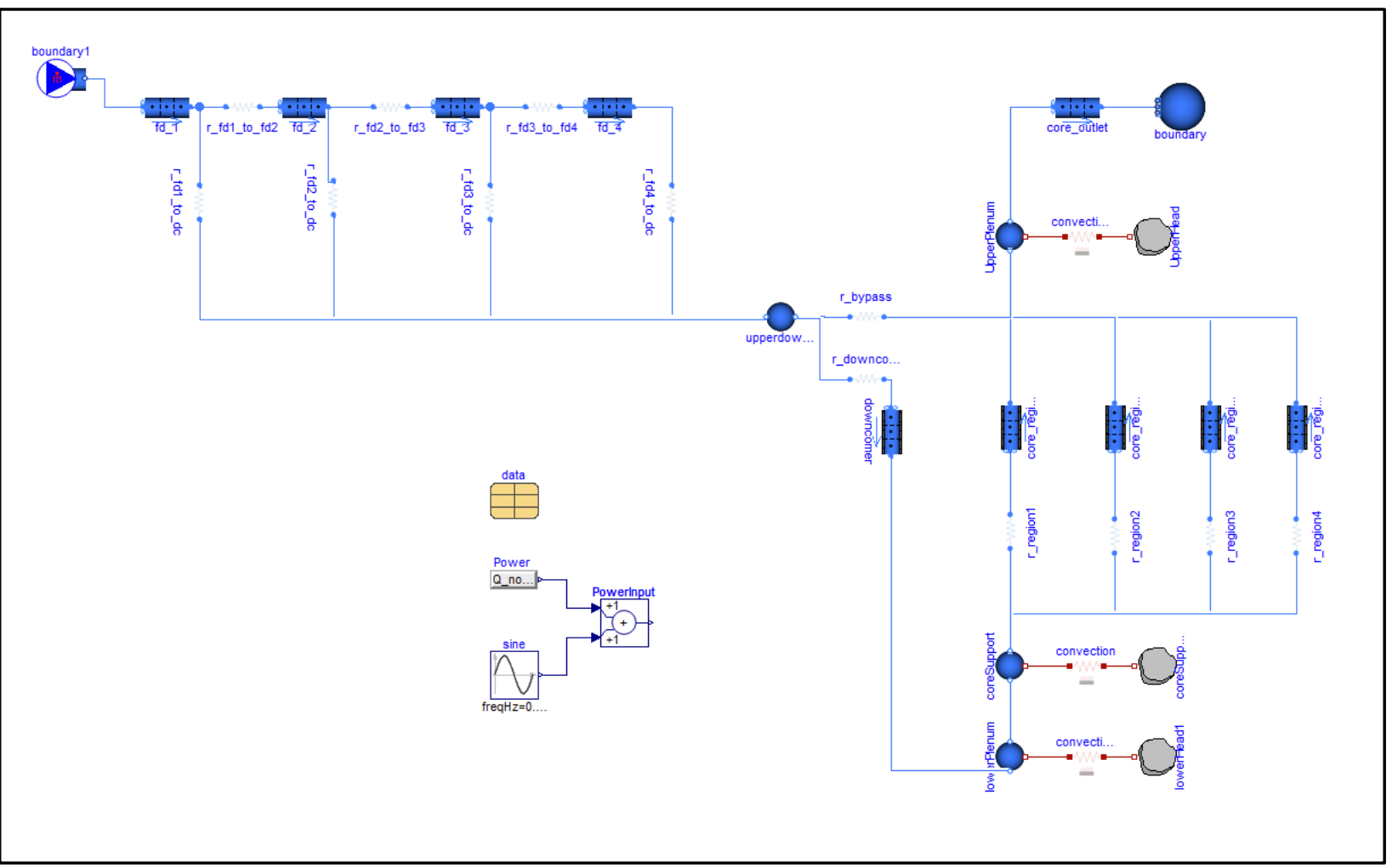

Figure 2. Completed model of the MSRE core. 


\subsection{PRIMARY FUEL SALT PROPERTIES}

To model the MSRE primary loop, it was necessary to add the fluid properties of the MSRE fuel salt to TRANSFORM. The initial measurements used in the MSRE design were later found to be incorrect. This led to differences between the expected thermal hydraulic performance of the reactor and the actual performance of the reactor once it was completed [16]. These values are summarized in Table 2. The reactor was only able to reach a full power of around 7.4 MWth rather than the design power of $10 \mathrm{MWth}$. It was found that the values for thermal conductivity were significantly lower than expected, which led to the reduced heat transfer performance. The properties were later updated, and the correct values were published. The design values and updated values are also shown in Table 2.

Table 2. MSRE Salt Physical Properties [1]

\begin{tabular}{|c|c|c|c|c|c|}
\hline \multirow[b]{2}{*}{ Property } & \multirow[b]{2}{*}{ Units } & \multicolumn{2}{|c|}{ Design values ${ }^{a}$} & \multicolumn{2}{|c|}{$\begin{array}{l}\text { ORNL-TM-3039 } \\
\text { values }^{b}\end{array}$} \\
\hline & & Fuel & Coolant & Fuel & Coolant \\
\hline Thermal conductivity & $\begin{array}{l}\mathrm{Btu} /\left(\mathrm{hr}-\mathrm{ft}-{ }^{\circ} \mathrm{F}\right) \\
(\mathrm{W} / \mathrm{m}-\mathrm{K})\end{array}$ & $\begin{array}{r}2.75 \\
(4.76)\end{array}$ & $\begin{array}{r}3.5 \\
(6.06)\end{array}$ & $\begin{array}{l}0.832 \\
(1.44)\end{array}$ & $\begin{array}{l}0.659 \\
(1.14)\end{array}$ \\
\hline Viscosity & $\begin{array}{l}\mathrm{lb} /(\mathrm{ft}-\mathrm{hr}) \\
\text { (centipoise) }\end{array}$ & $\begin{array}{r}17.9 \\
(7.4)\end{array}$ & $\begin{array}{r}20.0 \\
(8.27)\end{array}$ & $\begin{array}{r}18.7 \\
(7.73)\end{array}$ & $\begin{array}{r}23.6 \\
(9.76)\end{array}$ \\
\hline Density & $\begin{array}{l}\mathrm{lb} / \mathrm{ft}^{3} \\
\left(\mathrm{~kg} / \mathrm{m}^{3}\right)\end{array}$ & $\begin{array}{r}154.3 \\
(2,471.7)\end{array}$ & $\begin{array}{r}120.0 \\
(1,922.2)\end{array}$ & $\begin{array}{r}141.2 \\
(2,261.8)\end{array}$ & $\begin{array}{r}123.1 \\
(1,971.9)\end{array}$ \\
\hline Specific heat & $\begin{array}{l}\mathrm{Btu} /\left(\mathrm{lb}-{ }^{\circ} \mathrm{F}\right) \\
(\mathrm{J} / \mathrm{kg}-\mathrm{K})\end{array}$ & $\begin{array}{r}0.46 \\
(1,927)\end{array}$ & $\begin{array}{r}0.57 \\
(2,388)\end{array}$ & $\begin{array}{r}0.4735 \\
(1,984)\end{array}$ & $\begin{array}{r}0.577 \\
(2,418)\end{array}$ \\
\hline
\end{tabular}

The temperature-dependent physical properties of the MSRE primary salt were later published in an October 1975 report on fission product behavior in the MSRE [14]. These correlations were implemented in TRANSFORM for use in the MSRE model. The density, viscosity, thermal conductivity, and specific heat correlations are given below.

$$
\begin{array}{ll}
\rho=2.575-5.13 * 10^{-4} T\left({ }^{\circ} \mathrm{C}\right) & {\left[\frac{\mathrm{g}}{\mathrm{cm}^{3}}\right]} \\
\eta=0.116 * 10^{-3} e^{3755 / T\left({ }^{\circ} \mathrm{K}\right)} & \text { [centipoise }] \\
\lambda=1.0 & {\left[\frac{\mathrm{W}}{\mathrm{m}^{\circ} \mathrm{C}}\right]} \\
c_{p}=0.57 & {\left[\frac{\mathrm{cal}}{\mathrm{g}^{\circ} \mathrm{C}}\right]}
\end{array}
$$

Different correlations for the property values may be included in the future to gain a better understanding of how errors in the fluid property values impact the predicted reactor behavior. 


\subsection{THERMAL-HYDRAULIC OVERVIEW OF THE MSRE CORE}

The MSRE reactor core (Figure 3) consisted of an inlet pipe, flow distributor, annular downcomer, lower plenum, core support structures, horizontal graphite lattice, vertical graphite core barrel, upper plenum, and outlet nozzle.

Fuel salt flowed into the reactor vessel from the 5-inch Schedule 40 Hastelloy-N piping of the reactor cold leg at a temperature of around $632.2^{\circ} \mathrm{C}\left(1,170{ }^{\circ} \mathrm{F}\right)$ [1][3]. It entered a toroidal flow distributor wrapped around the upper circumference of the reactor vessel. Salt then flowed into the downcomer through stacks of orifice holes located in 28 locations around the upper portion of the reactor vessel [2][3]. This provided roughly equal azimuthal flow into the downcomer. The orifice holes were drilled at an angle, producing a large tangential component to the fluid flow [2]. As the fluid traveled down the downcomer, it slowed down and reoriented towards a more vertical flow path before entering the lower plenum [2]. In the lower plenum, anti-swirl vanes served to stop any remaining tangential component to the fluid flow while reducing the radial pressure gradient in the lower vessel head [2]. This was important, as the pressure gradient in the lower head drove the flow distribution into the channels of the reactor core.

At the top of the lower plenum, a grid of vertical Hastelloy-N plates was used as structural support for the graphite core barrel during shutdown [3]. Horizontal graphite bars above the grid were used to control the spacing of the graphite stringers [2]. The salt flowed through small gaps between the bars, accounting for the majority of the flow losses across the core [2]. From there, the salt flowed into the vertical flow channels formed by the vertical graphite stringers.

The graphite stringers were regularly spaced throughout most of the core barrel. The spacing was disrupted in the center of the core barrel to allow space for control rods and sampler baskets. The central part of the reactor core did not have horizontal graphite bars at the inlet, which greatly increased the fluid flow through this region of the core. The remainder of the core had roughly equal flow.

The relative flow rates through the core were measured in the full-scale test facility, providing a better understanding of the reactor core behavior. These tests included fluid residence time measurements, as well as heat transfer coefficient measurements at different locations in the core mock-up.

From the vertical channels, salt flowed into the upper plenum before exiting through the outlet at the top of the reactor vessel. During full power operation, the outlet temperature was normally around $654.4{ }^{\circ} \mathrm{C}$ $\left(1,210^{\circ} \mathrm{F}\right)$. Only the temperatures and neutron flux were measured in the reactor core during operation. The pressures and flow rates used in the model were based on predictions and measurements from the full-scale facility.

Heat was generated in the core through fissions in the fuel salt, as well as internal heating from gamma, beta, and neutron irradiation in core structures. Around $88 \%$ of the fissions occurred in the fuel channels, with $6 \%$ in the upper plenum, $3 \%$ in the downcomer, and $3 \%$ in the lower plenum [14]. The internal heat generation in the graphite and Hastelloy- $\mathrm{N}$ varied based on the location in the core. Estimations for the axial and radial profiles were published in the design documentation for the nuclear analysis of the MSRE [17]. 


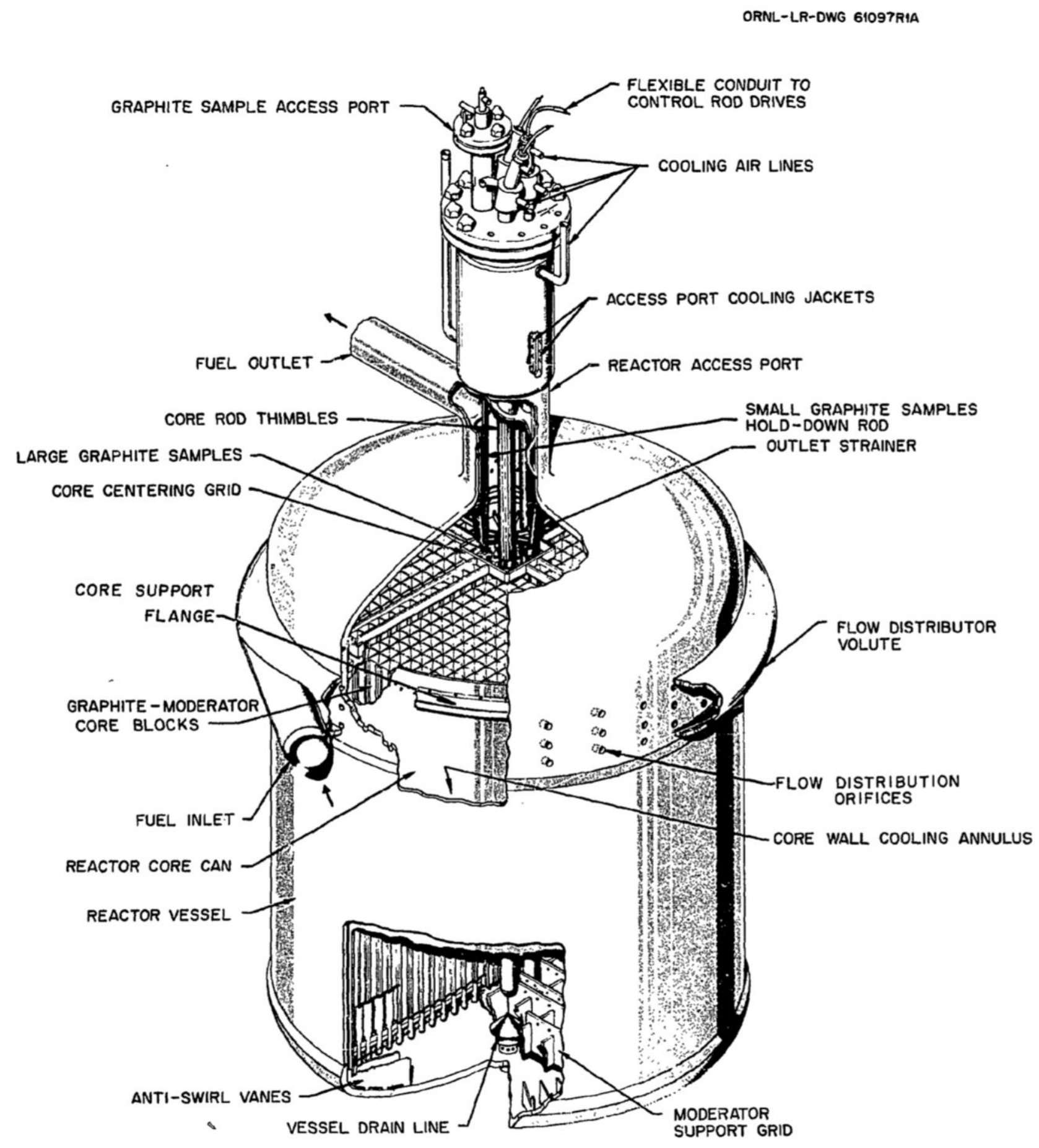

Figure 3. Overview of MSRE reactor core [2]. 


\subsection{FLOW DISTRIBUTOR}

During MSRE design, concerns about the structural integrity of the reactor vessel operating at such high temperatures led to the decision to use the fuel salt from the cold leg to cool the reactor vessel before the salt entered the core channels. This would preheat the salt while removing heat generated in the reactor vessel. This was done by flowing the cold leg salt through a downcomer consisting of the annular gap between the outer reactor vessel and the inner core can. It was important that the flow be evenly distributed azimuthally around the annulus to provide equal cooling. Therefore, a flow distributor was designed that wrapped around the upper circumference of the reactor vessel.

\section{Table 3. Flow Distributor Parameters}

\begin{tabular}{lr} 
Parameter & Value \\
\hline Hydraulic diameter $[$ in $(\mathrm{cm})]$ & $4.88(12.4)$ \\
Wetted perimeter $[$ in $(\mathrm{cm})]$ & $20.5(52)$ \\
Flow area $\left[\mathrm{in}^{2}\left(\mathrm{~cm}^{2}\right)\right]$ & $25(161.3)$ \\
Total length $[$ in $(\mathrm{cm})]$ & $200(508)$ \\
Length per pipe $[$ in $(\mathrm{cm})]$ & $50(127)$ \\
& $1200 \mathrm{gpm}$ \\
Volumetric flow rate $\left[\mathrm{gpm}\left(\mathrm{m}^{3} / \mathrm{s}\right)\right]$ & $\left(0.07571 \mathrm{~m}^{3} / \mathrm{s}\right)$ \\
& $\sim 376(\sim 170)$ \\
\hline
\end{tabular}

There are several potential ways to model the flow distributor. In the past, most models have treated it as a simple inlet pipe connecting to the downcomer inlet. For the purposes of the core model, this would have provided suitable results, as no heat generation is modeled in the flow distributor, and the fluid properties remain the same as the inlet boundary conditions. However, it was decided to model the variable flow distances into the downcomer, as later modeling will require a more accurate representation of the time lag and axial mixing of the fluid caused by the flow distributor. Experiments with the MSRE often used pulses of reactivity which translated into pulses of temperature change traveling through the piping. The variable residence time for fluid in the flow distributor caused some degree of axial mixing that would affect the temperature profile of the core. A basic approximation of this axial mixing was accomplished with the current nodalization, although future updates could improve the accuracy if needed.

The flow patterns in the flow distributor were well characterized during the full-scale flow loop testing [2]. The flow rates were measured at various points around the flow distributor, as well as azimuthally around the downcomer. The measurements showed a linear decrease in the flow rate around the flow distributor, with a small amount of recirculation back to the inlet. Measurements in the downcomer indicated roughly equal flow coming from the distributor, confirming that the design worked.

For the nodalization (Figure 4), the flow distributor was divided into four equal-length pipes. The first three pipes had flow branching to the downcomer and continuing into the flow distributor, and the fourth pipe was connected solely to the downcomer. Flow resistances were used to tune the flow into the downcomer relative to the flow that continued in the flow distributor. These resistances are summarized in Table 4. At the inlet, there was 1,200 gpm of flow, which equates to approximately $170 \mathrm{~kg} / \mathrm{s}$ for a density of $2245 \mathrm{~kg} / \mathrm{m}^{3}$ evaluated at $643.3^{\circ} \mathrm{C}$. The resistances between each flow distributor pipe were kept the same, while the flow resistances into the downcomer were tuned to achieve an equal flowrate of 
$42.5 \mathrm{~kg} / \mathrm{s}$ into the downcomer from each pipe. Table 3 provides the parameters used to model the flow distributor.

This model serves as a rough approximation of the axial mixing caused by the flow distributor, but it could be further improved by separately modeling the spaces between the locations between the 28 holes in the flow distributor while also adding recirculation to the inlet. The current configuration produces the desired effect while avoiding the additional complexity. It replicates the linear decrease in the flow velocity, with equal flow into the downcomer from each respective section of the flow distributor.

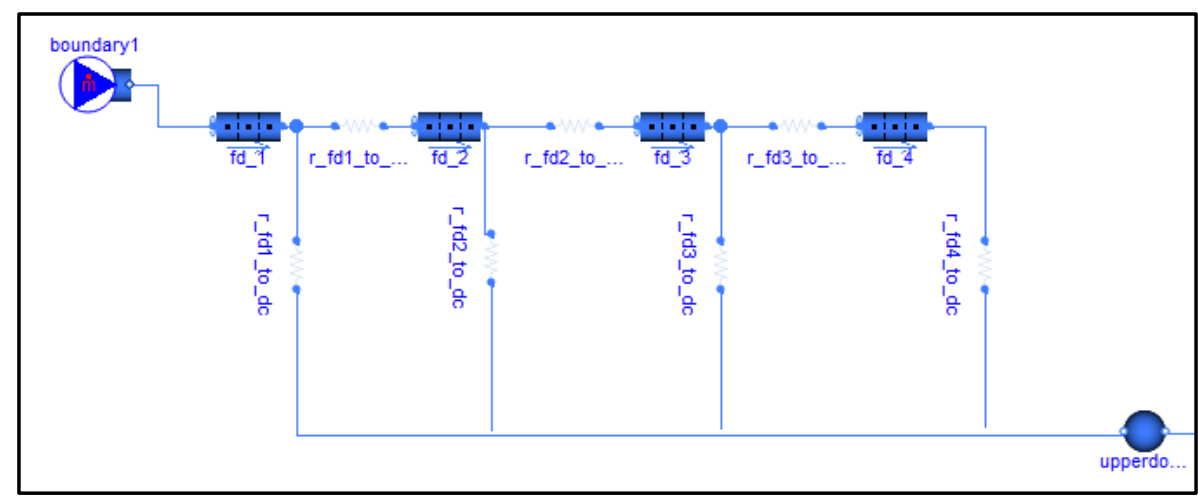

Figure 4. Nodalization of flow distributor

Table 4. Relative Resistances in Flow Distributor

\begin{tabular}{|c|c|c|}
\hline Parameter & $\begin{array}{c}\text { Relative } \\
\text { resistance }{ }^{a}\end{array}$ & $\begin{array}{c}\text { Flow rate } \\
{[\mathrm{kg} / \mathrm{s}]}\end{array}$ \\
\hline r_fd1_to_dc & 50 & 42.5 \\
\hline r_fd1_to_fd2 & 1 & 127.5 \\
\hline r_fd2_to_dc & 18.5 & 42.5 \\
\hline r_fd2_to_fd3 & 1 & 85 \\
\hline r_fd3_to_dc & 7.5 & 42.5 \\
\hline r_fd3_to_fd4 & 1 & 42.5 \\
\hline r_fd4_to_dc & 1.9 & 42.5 \\
\hline
\end{tabular}

\subsection{DOWNCOMER}

Salt flowed from the flow distributor into the annular downcomer of the reactor vessel. The downcomer consisted of the space between the 56-inch $(142 \mathrm{~cm})$ outer diameter core barrel and the 58 -inch $(147 \mathrm{~cm})$ inner diameter of the cylindrical portion of the reactor vessel [3]. It had a height of approximately 64 inches $(162.6 \mathrm{~cm})$ from the flow distributor inlet to the lower plenum [3]. There were small gaps in the support flange at the top of the downcomer annulus that allowed 24 gallons of bypass flow from the top of the downcomer directly to the upper plenum [3]. This served to cool the support flange and to prevent localized overheating due to internal heat generation in the metallic structures. This reduced the overall flow through the core, and it was added to the model by tuned flow resistances (Table 4). 
The downcomer was approximated in the model by a fluid pipe with the same height and flow area as the actual downcomer. The values used to model the downcomer are presented in Table 5. The pipe was divided into 10 vertical nodes with internal heat generation profiles for the fluid and vessel walls (Table 6). The hydraulic diameter, flow area, wetted perimeter, and heat transfer area were calculated based on the annular geometry. Around 3\% of the total fission power was produced in the downcomer region [14]. This heat generation was divided based on the axial profile calculated for the core's outermost region [17]. Heat transfer to the inner core can was not included in the nodalization to simplify current modeling efforts but may be added if necessary as an additional heat transfer surface in future versions. The internal heat generation was included for the outer vessel wall to represent heating from gamma, beta, and neutron irradiation. The values were derived from values calculated during the MSRE design [17]. These values were scaled down linearly from the expected power of $10 \mathrm{MWth}$ to the actual operation power of approximately 7.4 MWth. The average volumetric heat generation rate inside the wall was found to be approximately $175 \mathrm{~kW} / \mathrm{m}^{3}$.

To model the bypass flow from the downcomer to the upper plenum, a small volume was added at the upper portion of the downcomer (Figure 5). The bypass flow and flow into the downcomer were tuned with flow resistances to achieve the desired 24 gpm of bypass flow. The remaining $1176 \mathrm{gpm}$ flowed through the downcomer and the reactor core.

Table 5. Downcomer Nodalization Parameters

\begin{tabular}{|c|c|}
\hline Parameter & Value \\
\hline Number of volumes & 10 \\
\hline Hydraulic diameter [in $(\mathrm{cm})]$ & $2.00(2.54)$ \\
\hline Wetted Perimeter [in $(\mathrm{cm})]$ & $358(909.3)$ \\
\hline Flow area $\left[\mathrm{in}^{2}\left(\mathrm{~cm}^{2}\right)\right]$ & $179(1154.8)$ \\
\hline Total length [in] & $64(162.6)$ \\
\hline Heat transfer surface area $\left[\mathrm{in}^{2}\left(\mathrm{~cm}^{2}\right)\right]^{a}$ & $11,662(75,240)$ \\
\hline Wall thickness [in $(\mathrm{cm})]$ & $9 / 16(1.43)$ \\
\hline Volumetric flow rate $\left[\mathrm{gpm}\left(\mathrm{m}^{3} / \mathrm{s}\right)\right]$ & $\sim 1,176(0.07419)$ \\
\hline Heat transfer coefficient to wall $\left[\mathrm{W} / \mathrm{m}^{2} \mathrm{~K}\right][2]$ & 7,774 \\
\hline Mass flow rate $[\mathrm{kg} / \mathrm{s}]$ & $\sim 168$ \\
\hline Fraction of total fission power & 0.03 \\
\hline
\end{tabular}

$\boldsymbol{a}=$ For heat transfer to outer vessel wall only

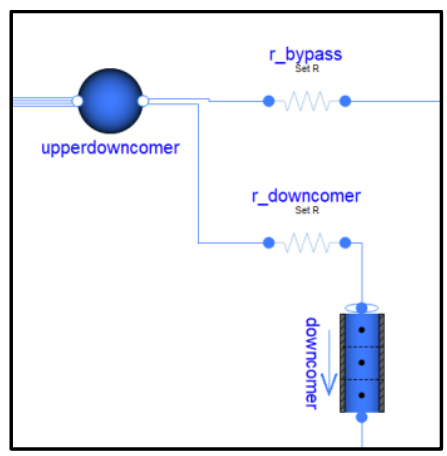

Figure 5. Nodalization of downcomer. 
Table 6. Downcomer Heat Generation Profiles

\begin{tabular}{rcc} 
Node & $\begin{array}{c}\text { Fraction of downcomer } \\
\text { fission power produced } \\
\text { in each axial node }\end{array}$ & $\begin{array}{c}\text { Internal heat generation } \\
\text { in vessel wall }\left[\mathbf{W} / \mathbf{m}^{\mathbf{3}}\right]\end{array}$ \\
\hline $\mathbf{1}$ & 0.0386 & 97,934 \\
$\mathbf{2}$ & 0.0760 & 143,731 \\
$\mathbf{3}$ & 0.103 & 183,224 \\
$\mathbf{4}$ & 0.1217 & 212,159 \\
$\mathbf{5}$ & 0.1328 & 227,539 \\
$\mathbf{6}$ & 0.135 & 229,629 \\
$\mathbf{7}$ & 0.129 & 216,485 \\
$\mathbf{8}$ & 0.114 & 190,471 \\
$\mathbf{9}$ & 0.0916 & 152,079 \\
$\mathbf{1 0}$ & 0.0581 & 96,849 \\
\hline
\end{tabular}

\subsection{LOWER PLENUM}

Fuel salt flowed from the downcomer into the lower plenum of the reactor vessel. The lower plenum of the MSRE consisted of the lower vessel head, the anti-swirl vanes, the drain line hood, and the Hastelloy$\mathrm{N}$ support structures. Around 3\% of the total fission power was produced in the lower plenum, with additional internal heat generation in the vessel walls of around $0.2 \mathrm{~W} / \mathrm{cm}^{3}$ [14]. The lower head fluid volume was cited as being 12.24 cubic feet [14]. In the model shown in Figure 6, this volume was divided between a lower plenum fluid volume (80\%) and a core support fluid volume (20\%). This was done to separate heat transfer to the lower vessel head and the core support structures. Simple mixing volumes were used for both volumes with convective heat transfer to respective thermal masses. The heat transfer calculations used heat transfer coefficients of $3,064 \mathrm{~W} / \mathrm{m}^{2}-\mathrm{K}$ measured during the operation of the fullscale flow loop experiments [2].

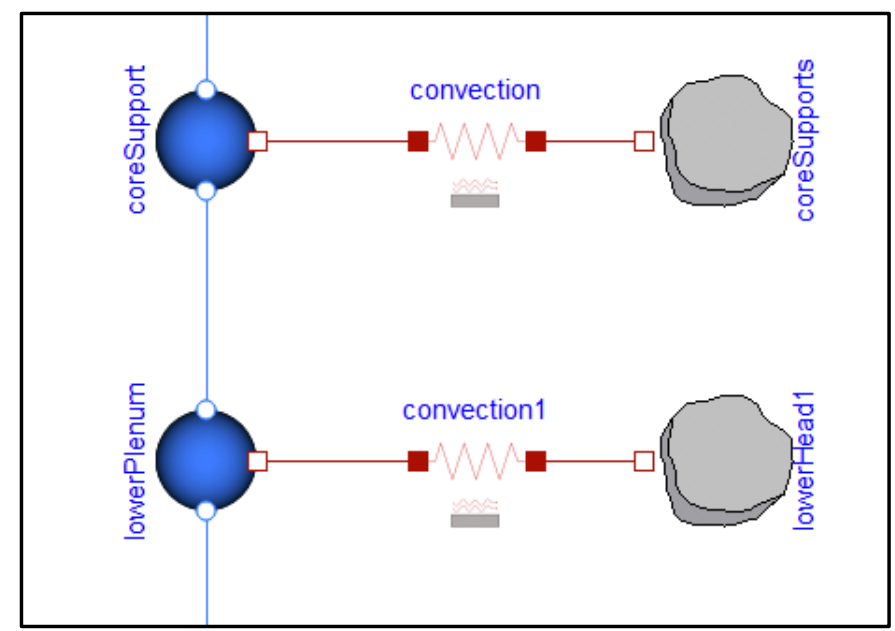

Figure 6. Lower plenum nodalization. 


\subsection{CORE CHANNEL INLET FLOW}

In the MSRE core there were horizontal graphite bars located below the vertical graphite stringers that controlled the spacing of the stringers. There were two layers of horizontal bars oriented perpendicular to one another. The fuel salt flowed through the gaps between bars into the fuel channels. This design was responsible for the majority of the flow losses across the core, and it controlled the relative flow into the vertical graphite stringer channels [2]. To model the relative flow into the core channels, flow resistances were used to tune the flow profile to match the measurements obtained from the full-scale experimental facility [2].

\subsection{CORE REGIONS}

The main section of the MSRE core consisted of vertical graphite stringers stacked together to form vertical fuel salt channels. The fuel salt reached a critical configuration in the channels. Fissions in the channels were responsible for $88 \%$ of the total fission power generation [14]. The remainder of the fission power was generated in the downcomer, lower plenum, and upper plenum [14]. The regular spacing of the graphite stringers was discontinued in the center of the core to allow room for the control rod thimbles and sampler baskets (Figure 9). There were no horizontal graphite stringers below this central region of the core, allowing for a greatly increased flow rate. The other areas of the reactor core had roughly equal flow rates through the fuel channels, with a velocity of approximately $0.7 \mathrm{ft} / \mathrm{sec}$ [2]. In total there were around 1,140 equivalent full channels in the reactor core [3].

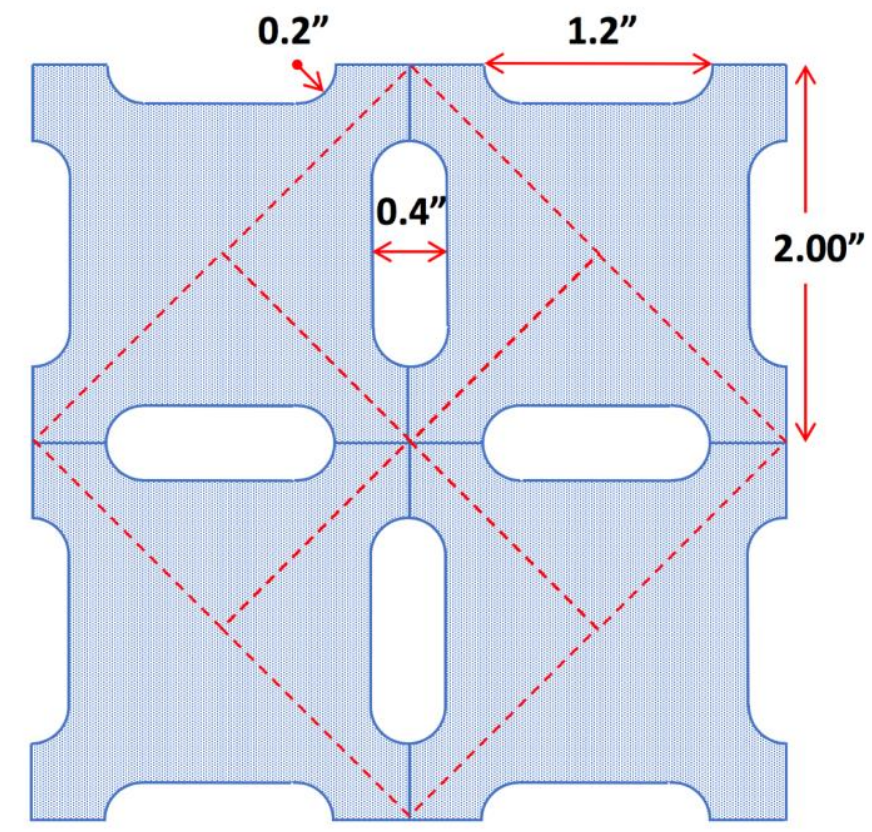

Figure 7. Fuel channels formed with graphite stringers.

\subsubsection{Approximation of Individual Fuel Channel}

The fuel channel geometry in the model is approximated by an equivalent circular channel with a cylindrical graphite wall, as shown in Figure 8. The graphite pipe wall thickness was calculated to preserve the total area of graphite. This served to preserve the total graphite volume in the core. The heat transfer surface area between the salt and graphite was found using the original geometry rather than the area found using the cylindrical approximation. Table 7 provides the parameters from the individual fuel channel approximation. By using a cylindrical geometry with an equivalent graphite volume, the 
approximation slightly overpredicts the temperature at the stringer corners, while it underpredicts the centerline temperature of the stringers. An alternative approach would be to create an approximate graphite channel with heat transfer to a slab that is equivalent to the distance to the center of the graphite stringer. This would allow for a more accurate prediction of the graphite center temperature while artificially increasing the graphite volume of the reactor core.

Table 7. Individual Fuel Channel Approximation

\begin{tabular}{lr} 
Parameter & Value \\
\hline Number of axial nodes & 10 \\
\hline Hydraulic diameter [in $(\mathrm{cm})]$ & $0.624(1.585)$ \\
\hline Wetted perimeter $[\mathrm{in}(\mathrm{cm})]$ & $2.857(7.257)$ \\
\hline Flow area [in $\left.{ }^{2}\left(\mathrm{~cm}^{2}\right)\right]$ & $0.446(2.88)$ \\
\hline Total length [in $(\mathrm{cm})]$ & $62(157.5)$ \\
\hline Heat transfer surface area $\left[\mathrm{in}^{2}\left(\mathrm{~cm}^{2}\right)\right]$ & $177(1142)$ \\
Graphite wall thickness $[\mathrm{in}]$ & $0.421(1.07)$ \\
Measured flow velocity $[\mathrm{ft} / \mathrm{s}(\mathrm{m} / \mathrm{s})]^{a}$ & $0.7(0.2134)$ \\
Graphite area $\left[\right.$ in $\left.^{2}\left(\mathrm{~cm}^{2}\right)\right]$ & $1.554(10)$ \\
\hline Typical volumetric flow rate $\left[\mathrm{gpm}\left(\mathrm{m}^{3} / \mathrm{s}\right)\right]$ & $1.0\left(6.31 \cdot 10^{-5}\right)$ \\
\hline $\boldsymbol{a}=$ From full-scale test facility $[2]$ &
\end{tabular}

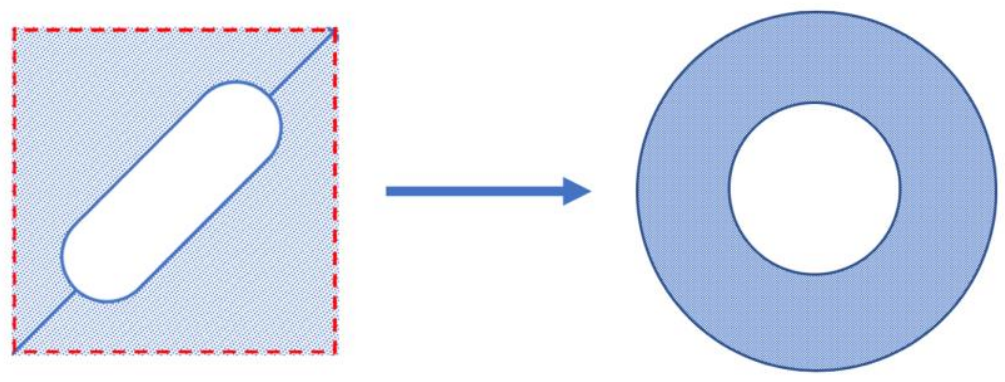

Figure 8. Approximation of individual fuel channel.

\subsubsection{Core Nodalization Approach}

The core was divided into four radial regions for the purposes of calculating heat generation and fluid flow profiles. The four radial regions, as approximated, are shown in Figure 10. The central region of the core consisted of the space for the control rod thimbles and sampler baskets, as well as the fuel channels in the central region. This was considered region 1 of the core, with region 4 being the outermost region. The other regions of the core used the individual fuel channel approximation with the number of parallel components equal to the number of channels from each respective region. Table 9 provides a summary of the approximate values for each region. 


\subsubsection{Central Region of Core}

The central region of the core had eight full fuel channels, three control rod channels, and one sampler basket channel, as shown in Figure 9. The central channel was approximated with a single fluid channel with a graphite wall. An equivalent channel was used based on the calculated flow area, wetted perimeter, graphite heat transfer area, graphite volume, and total height from the central region of the core. This is summarized in Table 8. The channel included internal heat generation in the fluid for fission power and internal heat generation in the wall for irradiation heating.

Table 8. Parameters for Central Region (Region 1)

\begin{tabular}{lr} 
Parameter & Value \\
\hline Number of Axial Nodes & 10 \\
Hydraulic diameter [in $(\mathrm{cm})]$ & $0.872(2.215)$ \\
Wetted Perimeter $[$ in $(\mathrm{cm})]$ & $55(140)$ \\
Flow area $\left[\mathrm{in}^{2}\left(\mathrm{~cm}^{2}\right)\right]$ & $11.9(76.8)$ \\
Total length $[$ in $(\mathrm{cm})]$ & $64(162.6)$ \\
Heat transfer surface area $\left[\mathrm{in}^{2}\left(\mathrm{~cm}^{2}\right)\right]$ & $1200(7742)$ \\
Graphite area $\left[\mathrm{in}^{2}\left(\mathrm{~cm}^{2}\right)\right]$ & $18.65(120.3)$ \\
Typical volumetric flow rate $\left[\mathrm{gpm}\left(\mathrm{m}^{3} / \mathrm{s}\right)\right]$ & $\sim 17(\sim 0.001073)$ \\
\hline
\end{tabular}

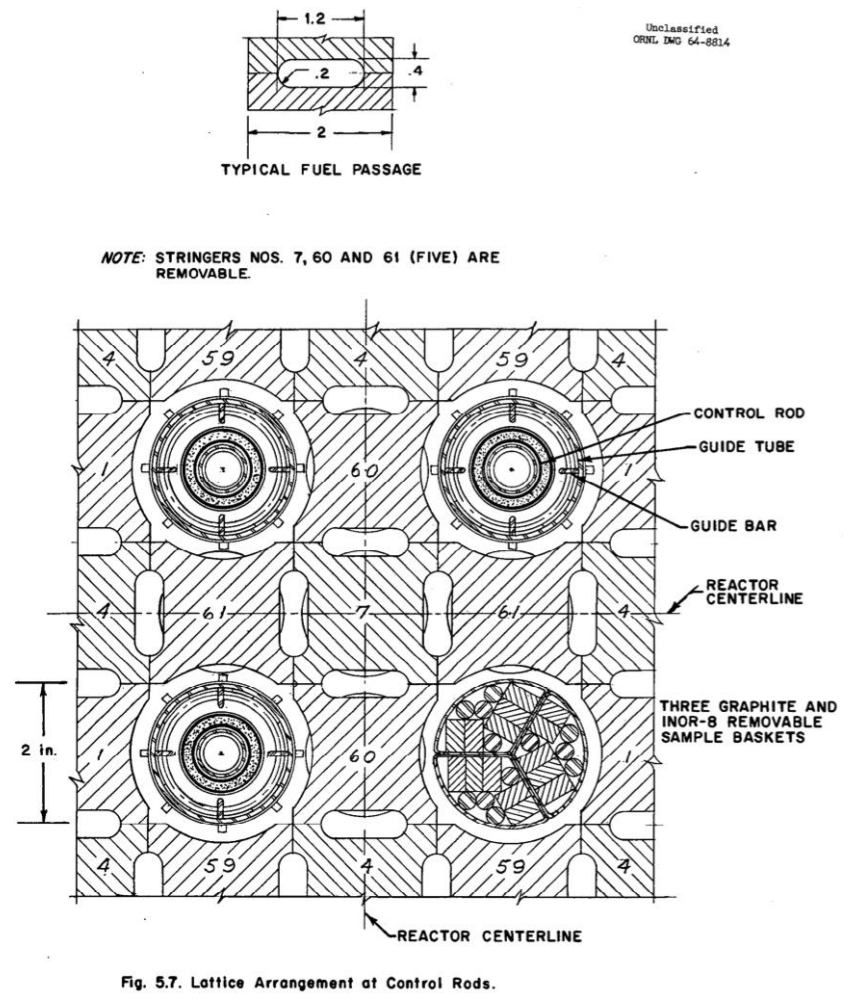

Figure 9. Horizontal cross-section of the MSRE core central region [3]. 


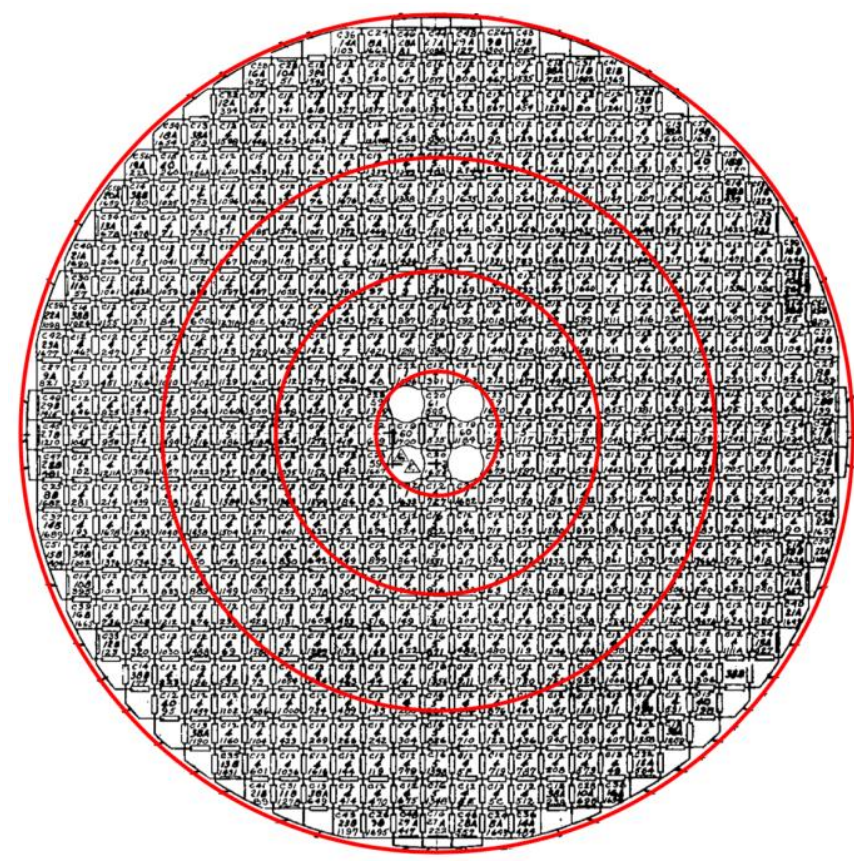

Figure 10. Cross section of graphite core with regions 1-4 [18].

Table 9. Summary of Core Regions

\begin{tabular}{lccc} 
Parameter & $\begin{array}{c}\text { Outer radius } \\
\text { [inch] }\end{array}$ & Number of channels & $\begin{array}{c}\text { Total flow rate } \\
{[\mathbf{k g} / \mathbf{s}]}\end{array}$ \\
\hline Region 1 & 4.18 & $\sim$ & 17 \\
Region 2 & 10.85 & 156 & 24 \\
Region 3 & 18.52 & 360 & 51 \\
Region 4 & 28.2 & 598 & 80 \\
\hline
\end{tabular}

\subsubsection{Fission Power Generation Profiles}

The axial and radial fission power density plots from ORNL-TM-730 Figures 3-11 and 3-12 were used to calculate the fission power profile for each node of the core. The fission power density was averaged for each region of the core, normalized, and then scaled for $88 \%$ of the total fission power of 7.4 MWth, or 6.512 MWth. The resulting profiles are shown in Figure 11. The control rods caused a decrease in the fission power density near the center of the core. This resulted in the majority of fission power being produced in region 2, with the power profiles in region 1 and region 3 being roughly equal. 


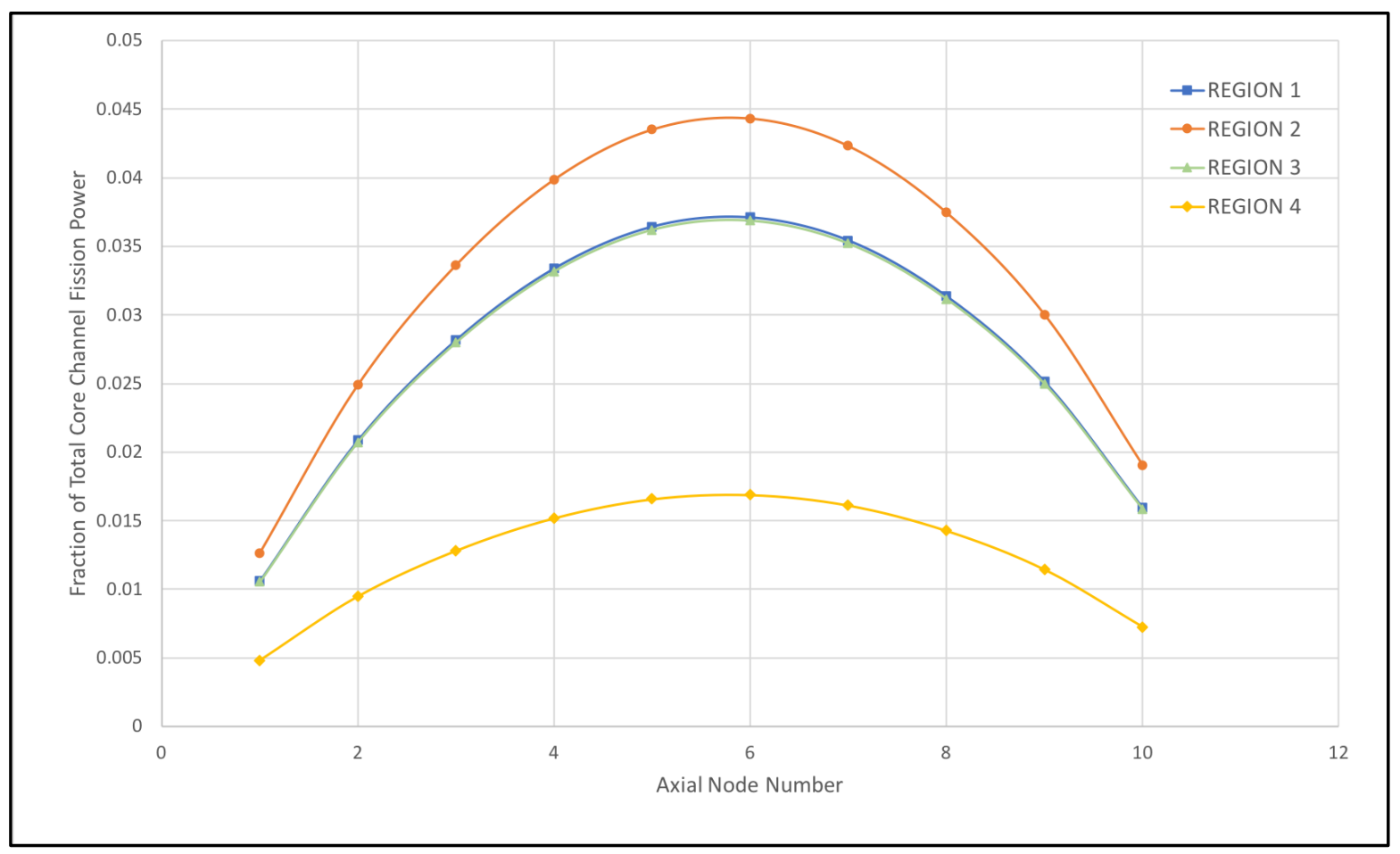

Figure 11. Fission power distribution for core channels.

\subsubsection{Profiles for Internal Heat Generation in Graphite}

Figures 14-1 and 14-2 from ORNL-TM-730 gave the axial and radial profiles for heat generation in the graphite caused by a combination of gamma, beta, and neutron irradiation. These were used to calculate the internal heat generation profiles for the graphite in the TRANSFORM model, as presented in Figure 12. The resulting values were linearly scaled from the design power of $10 \mathrm{MWth}$ to the normal operating power, which was typically 7.4 MWth.

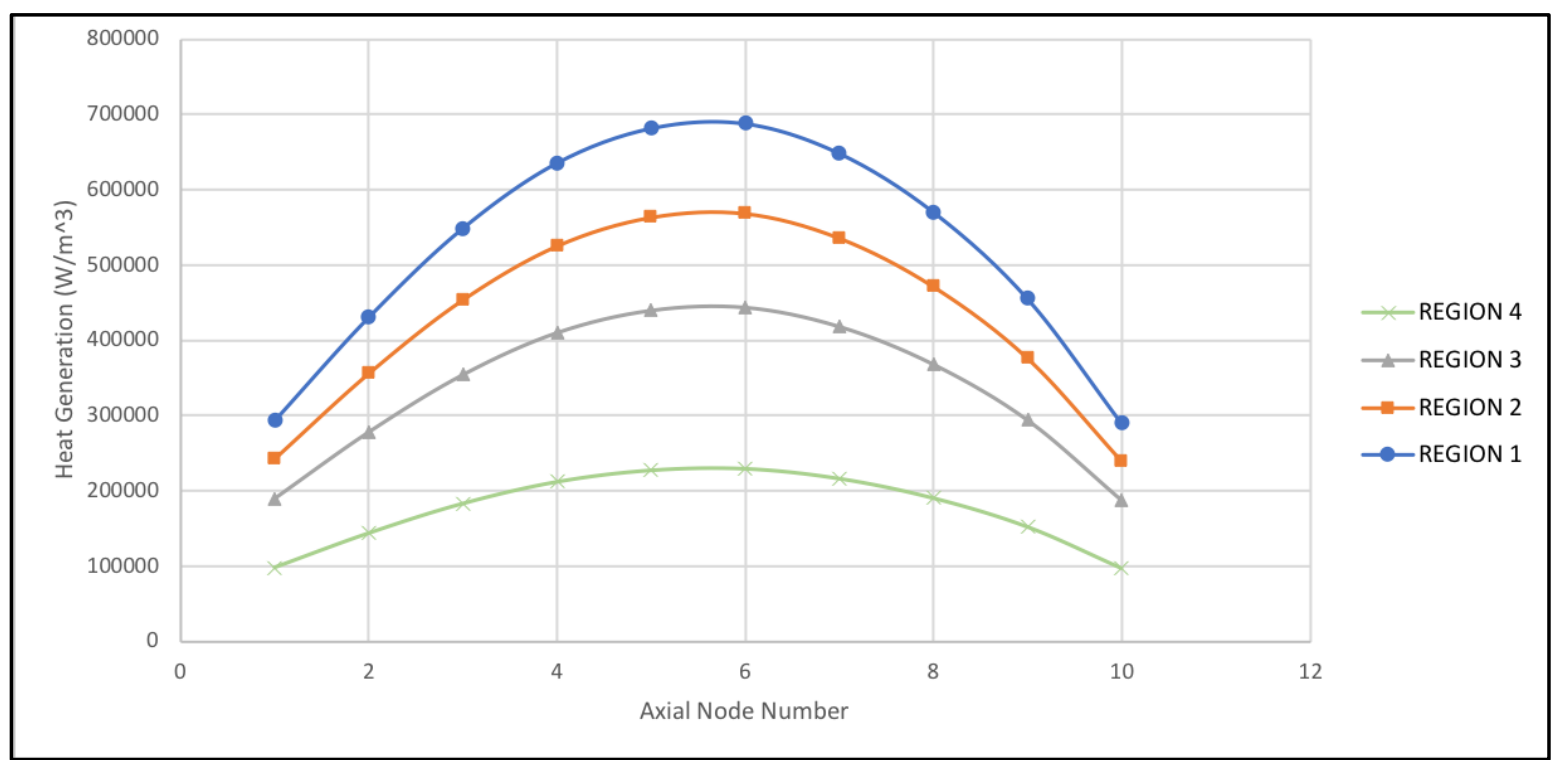

Figure 12. Core graphite internal heat generation. 


\subsection{UPPER PLENUM}

The fuel salt flowed from the fuel channels into the upper plenum of the reactor vessel, where 6 percent of the fission power was generated [14]. The upper plenum contained the upper core support structures, control rod thimbles, sampler basket thimbles, and graphite strainer [3]. This was modeled using a single mixing volume with convective heat transfer to a thermal mass (Figure 13). The fluid volume of the upper plenum was approximately 11.34 cubic feet [14]. The upper plenum combined the flows from the core bypass and fuel channels. The salt then flowed out of the reactor vessel through the upper outlet nozzle. During operation, the reactor outlet temperature was measured with a thermocouple on the surface of the pipe at the reactor outlet nozzle. At full power, this was typically around $654.4^{\circ} \mathrm{C}\left(1210{ }^{\circ} \mathrm{F}\right)$, although values presented in ORNL-TM-3039 are slightly lower.

The upper plenum also contained a volume above the outlet nozzle referred to as the reactor access nozzle. This provided a penetration point for the control rods while allowing for access into the reactor vessel during shutdown. For simplicity, this was not included in the model.

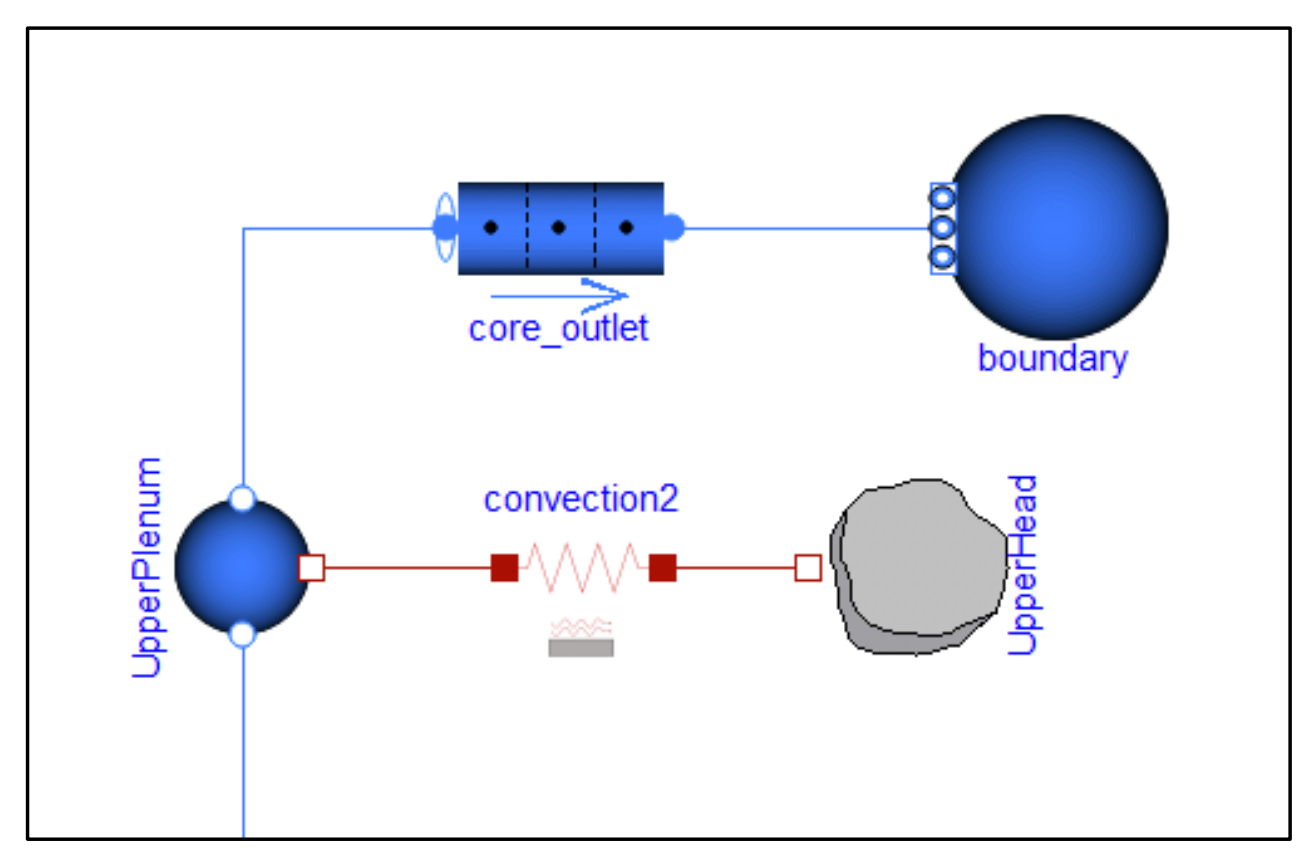

Figure 13. Upper plenum nodalization. 


\section{PRELIMINARY RESULTS}

This section describes the initial results from the MSRE core model. Further comparisons beyond what is discussed here will be used to validate various aspects of the model in the future. For an initial check, the model boundary conditions were set to the known flow rate, cold leg temperature, and power reported in ORNL-TM-3039. The model was able to accurately predict the steady state values of interest. The core outlet temperature was predicted within the uncertainty of the instrumentation. However, it was more important to validate the transient heat transfer performance of the core model. For this, a frequency domain comparison was used.

\subsection{FREQUENCY DOMAIN COMPARISON OF CORE HEAT TRANSFER BEHAVIOR}

The MSRE primary loop instrumentation was largely limited to surface thermocouples and neutron flux measurements, making it difficult to validate many aspects of the reactor core model. However, some information on the transient heat transfer behavior of the reactor core does exist with regards to the relationship between the core outlet temperature and reactor power [15]. The frequency response relationship was calculated from data obtained during several experiments throughout operation with both $\mathrm{U}^{235}$ and $\mathrm{U}^{233}$ fuel. These measurements were originally associated with a power of $8 \mathrm{MWth}$. The heat balance calculations were later updated using updated fluid property values for a predicted power of 7.6 MWth. The model used the later power value to calculate the system response.

This frequency domain characterization of this relationship provides a concise description of the core heat transfer behavior over a variety of timescales. This has proven to be valuable for model validation efforts as compared to a single time domain transient that may not perturb the system at all relevant time scales. The gain of the frequency response relationship between the core's outlet temperature and reactor power was calculated for the model and compared to the experimentally determined values as part of the initial model validation efforts. The results of this comparison are presented in Figure 14. The phase angle relationship was not calculated for the TRANSFORM model but will be included in future comparisons.

Figure 14 shows the experimental data obtained during the testing with different fissionable material used in operation. During operation with $\mathrm{U}^{235}$, it was found that heat transfer changes in the radiator were causing temperature perturbations in the core [19]. There was also interest in better understanding mixing in the primary loop, as this was difficult to predict with analytical models [19]. This led to a study of the relationship between the fuel outlet temperature and reactor power $(\delta T / \delta n)$ [19]. This relationship is a function of the thermal properties in the core, which did not change significantly between the different fuel loadings [15].

The experimental data in Figure 14 show an attenuation in the gain at higher frequencies, as a given perturbation in power has a diminishing impact on the fluid outlet temperature with increasing frequency. Predicting the magnitude of this attenuation has been a challenge for previous modeling efforts [15] [19]. The attenuation is the result of several effects. These include the magnitude and location of internal heat generation in the fuel salt, the magnitude and location of internal heat generation in the structures, heat transfer between the fuel and the structures, as well as mixing of the fluid. The higher frequency results are also impacted by the location and response of the thermocouple used for making the temperature measurement. 
For this system, the gain would be expected to approach a constant value as the frequency approaches zero. The theoretical results presented in ORNL-TM-2571 predict a constant gain around a frequency of $10^{-4}$ radians per second [19]. The TRANSFORM model predicts a constant gain at much higher frequency, as it does not model the other components of the MSRE that are known to impact the behavior below $10^{-2}$ radians per second. The validation efforts are limited by the frequency range of experimental results, which were not obtained for frequencies below 0.0035 radians per second. The low frequency behavior will be reevaluated once the full model is completed.

The TRANSFORM model of the core as currently modeled provides a better prediction of behavior at higher frequencies when compared to the ORNL-TM-2997 theoretical results, while underpredicting the magnitude across all frequencies. There are a number of possible explanations for the underprediction of the gain that will be discussed and investigated in the future.

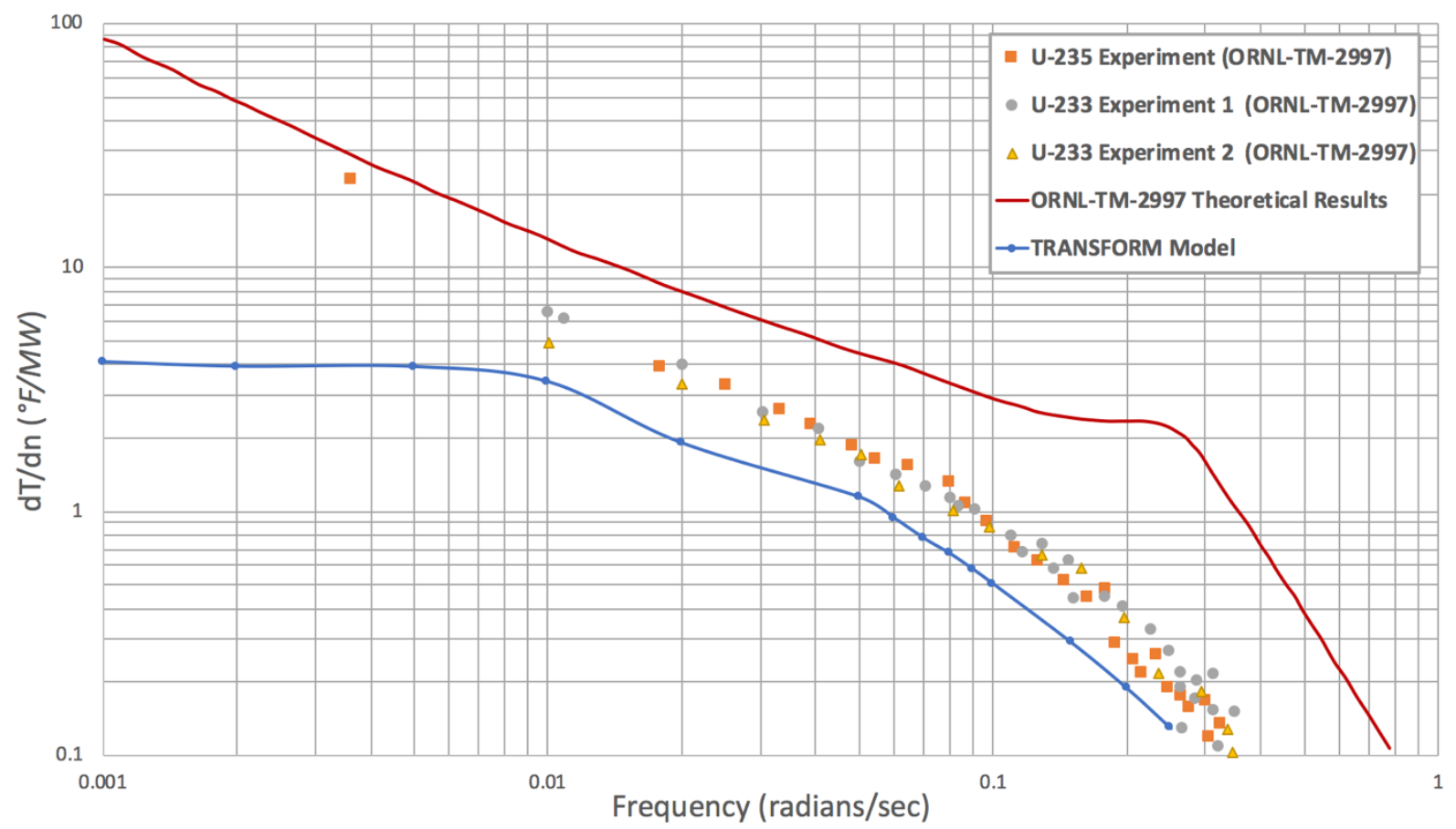

Figure 14. Comparison of frequency response for core outlet temperature to reactor power.

\subsection{DISCUSSION OF PRELIMINARY RESULTS}

The TRANSFORM model was created using values from the full-scale experimental facility combined with predictions for the heat generation profiles used during design. This is similar to the information that was available to researchers at the time, while updated values were used for the physical properties of the fuel salt. As shown in Figure 14, the frequency response calculations from the uncalibrated model show good agreement with the heat transfer behavior of the reactor core while slightly underpredicting the magnitude of the gain.

The theoretical frequency response calculations for the core outlet temperature's relationship to the reactor's power were originally calculated with a slight variation of a $44^{\text {th }}$-order nodal model of the 
reactor [19]. That ORNL-TM model's behavior was significantly different than that indicated by the experimental values, making it difficult for analysts to draw any conclusions from the comparison [15]. Although the TRANSFORM model in its current form performs well, it should be noted that the original experimental gain calculations were based on a slightly flawed correlation for converting neutron flux to reactor power. Heat balance calculations were used for calibration of the reactor power. After operation, it was discovered that the heat balance corresponding to 8 MWth was actually around 7.6 MWth [1] [14]. Isotopic analysis of the fuel salt after operation provided a value of approximately 7.4 MWth [14]. Therefore, the experimental may itself have some fundamental flaws which may shift its values though not on the order expected to meet the original ORNL-TM model, thus experimental and model data may not be expected to match exactly. The location and response time of the thermocouple used for measuring the reactor core outlet temperature can also have a large effect on the magnitude and phase of the measured response to a change in power. The transfer function is also impacted by power-dependent internal heat generation in the pipe wall near the thermocouple. Further investigation is needed to better understand the exact positioning of the thermocouple relative to the flowing fuel salt, as well as the nature of power-dependent heat generation near the thermocouple.

With regards to the TRANSFORM model, there are several other possible explanations for differences in the magnitude of the gain. The model ignores induced turbulence at the inlet of the fuel salt channels, which slightly underpredicts the heat transfer coefficient between the graphite and the fuel salt. Artificially increasing the heat transfer coefficient increases the gain of the relationship between the reactor power and the outlet temperature for a small increase in the heat transfer coefficient. Another possibility could be an error in the fluid property values. The property values used in the model come from ORNL-4865, which cites ORNL-4658 [20]. Other fluid property values exist in other publications that conflict with these values, although it is believed that ORNL-4658 has the most accurate correlations. Notably, the value for thermal conductivity published in ORNL-TM-3039 (Table 2) is $1.44 \mathrm{~W} / \mathrm{m}-\mathrm{K}$, which is higher than the ORNL-4658 value of $1.0 \mathrm{~W} / \mathrm{m}-\mathrm{K}$ (Equation 3). Further analysis will be performed after the balance of the model is completed to avoid any premature conclusions and wasted efforts. 


\section{FUTURE WORK}

With the model of the core complete, the next steps will focus on adding the other components of the MSRE to create a complete model of the reactor's primary and secondary loops. The completed model will then be compared with typical steady-state values found in ORNL-TM-3039. For transient model validation, the model will be compared to results from ORNL CF 68-5-11 and ORNL-TM-2997. A preliminary nodalization for the full model is shown in Figure 15.

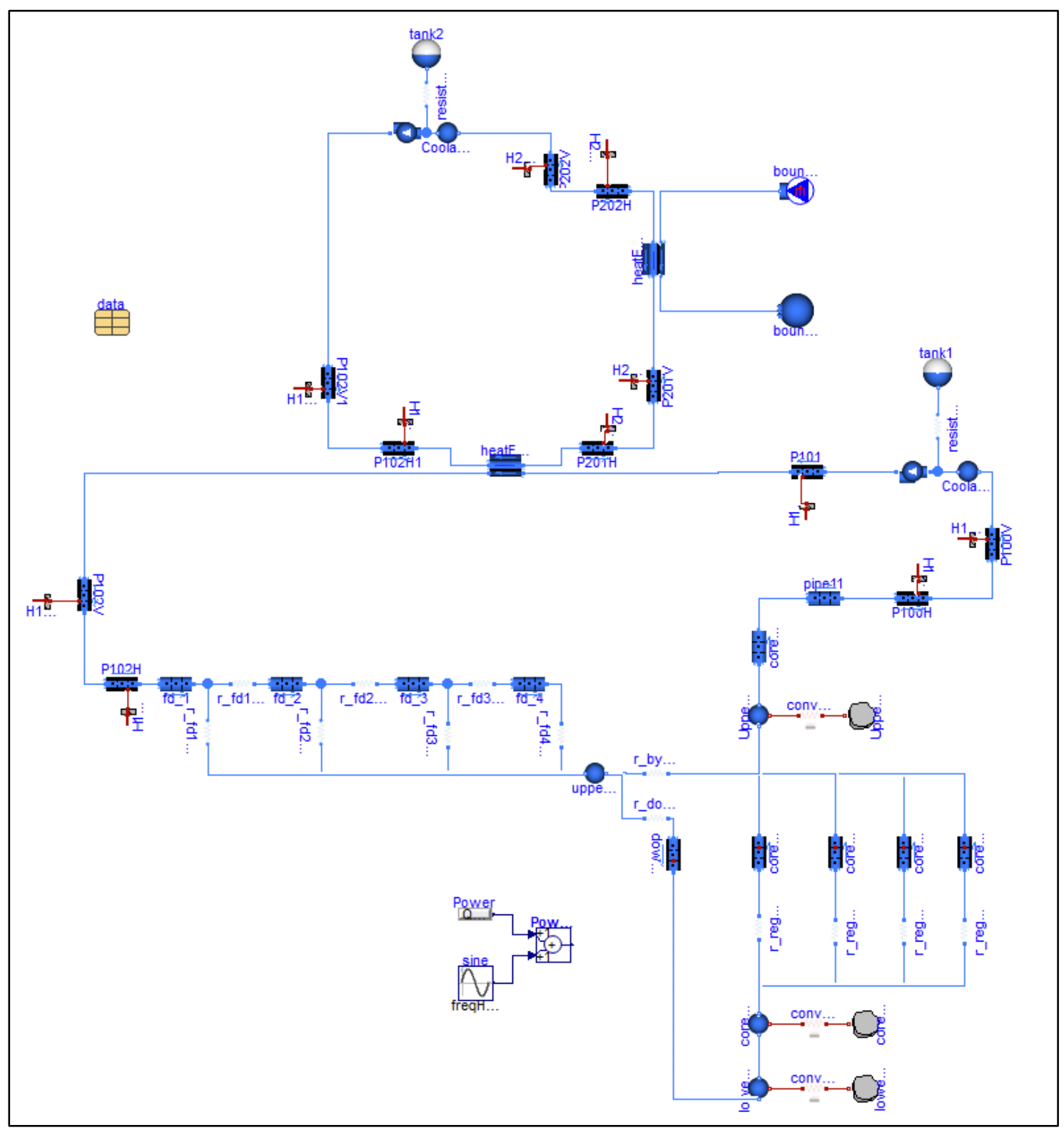

Figure 15. Preliminary nodalization for the full MSRE model. 


\section{BIBILOGRAPHY}

[1] R. H. Guymon. "MSRE Systems and Component Performance," ORNL-TM- 3039, Oak Ridge National Laboratory, Oak Ridge, Tennessee, June 1973.

[2] R. J. Kedl. "Fluid Dynamic Studies of the Molten-Salt Reactor Experiment Core," ORNL-TM-3229, Oak Ridge National Laboratory, Oak Ridge, Tennessee, Nov. 1970.

[3] R. C. Robertson. "MSRE Design and Operations Report Part I: Description of Reactor Design," ORNL- TM-728 Oak Ridge National Laboratory, Oak Ridge, Tennessee, Jan. 1965.

[4] Modelica Association, "Modelica and the Modelica Association." https://www.modelica.org/ (current as of Aug. 16, 2017).

[5] Modelica Association, "Modelica Language Specification Version 3.4." Modelica Association (2017).

[6] M. S. Greenwood, "TRANSFORM - Transient Simulation Framework of Reconfigurable Models." Modelica, Oak Ridge National Laboratory (2017); https://doi.org/10.11578/dc.20171109.1.

[7] M. S. Greenwood, "Component Development for Nuclear Hybrid Energy Systems." presented at the $12^{\text {th }}$ International Modelica Conference, 7 May 2017, Prague, Czech Republic, 839-846; https://doi.org/10.3384/ecp17132839.

[8] M. S. Greenwood, D. W. Fugate, and S. M. Cetiner, "Control Systems for a Dynamic Multi-Physics Model of a Nuclear Hybrid Energy System," presented at the $10^{\text {th }}$ International Topical Meeting on Nuclear Plant Instrumentation, Control, and Human-Machine Interface Technologies, 11 June 2017, San Francisco, CA (United States).

[9] S. M. Cetiner et al., "Supervisory Control System for Multi--Modular Advanced Reactors," ORNL/TM-2016/693, Oak Ridge National Laboratory, Oak Ridge, Tennessee, 2016.

[10] R. Hale et al., "Update on ORNL TRANSFORM Tool: Preliminary Architecture/Modules for HighTemperature Gas-Cooled Reactor Concepts and Update on ALMR Control," ORNL/SPR-2015/367, Oak Ridge National Laboratory, Oak Ridge, Tennessee, 2015.

[11] J. D. Rader, M. S. Greenwood, and P. W. HUMRICKHOUSE, "Verification of Modelica-Based Models with Analytical Solutions for Tritium Diffusion," Nucl. Technol. 1 (2018), https://doi.org/10.1080/00295450.2018.1431505.

[12] M. S. Greenwood and B. R. Betzler, "Modified Point Kinetic Model for Neutron Precursors and Fission Product Behavior for Fluid-Fueled Molten Salt Reactors," Nucl. Sci. Eng. (In Press); https://doi.org/10.1080/00295639.2018.1531619.

[13] M. S. Greenwood, B. R. Betzler, and A. L. Qualls, "Dynamic System Models for Informing Licensing and Safeguards Investigations of Molten Salt Reactors," ORNL/TM-2018/876, 1456790 Oak Ridge National Laboratory, Oak Ridge, Tennessee, 2018, https://doi.org/10.2172/1456790.

[14] E. L. Compere. "Fission Product Behavior in the Molten Salt Reactor Experiment," ORNL-4865, Oak Ridge National Laboratory, Oak Ridge, Tennessee, October 1975.

[15] R. C. Steffy Jr. "Experimental Dynamic Analysis of the MSRE with U-233 Fuel," ORNL-TM-2997, Oak Ridge National Laboratory, Oak Ridge, Tennessee, Oak Ridge, TN, Jan. 1970. doi: 10.2172/4132458. url: http://www.osti.gov/servlets/purl/4132458/.

[16] C. H. Gabbard. "Reactor Power Measurement and Heat Transfer Performance in the Molten Salt Reactor Experiment,” ORNL-TM-3002, Oak Ridge National Laboratory, Oak Ridge, Tennessee, May 1970. 
[17] P. N. Haubenreich. "MSRE Design and Operations Report Part II: Nuclear Analysis," ORNL-TM-730. Oak Ridge National Laboratory, Oak Ridge, Tennessee, Feb. 1964.

[18] H. E. McCoy and B. McNabb. "Postirradiation Examination of Materials from the MSRE," ORNL-TM-4174. Oak Ridge National Laboratory, Oak Ridge, Tennessee, Dec. 1972.

[19] R. C. Steffy, Jr. and P. J. Wood. "Theoretical Dynamic Analysis of the MSRE with U-233 Fuel," ORNL-TM-2571. Oak Ridge National Laboratory, Oak Ridge, Tennessee, July 1969.

[20] R. E. Thoma. "Chemical Aspects of MSRE Operation," ORNL-4658. Oak Ridge National Laboratory, Oak Ridge, Tennessee, Dec. 1971. 